\title{
Do Mobile Technology in the Classroom Really Improve Learning Outcomes?
}

\author{
Shazia Zaheer ${ }^{1}$, Saad M Butt ${ }^{2}$, Gnevasheva Vera Anatolyevna ${ }^{3}$, Hosna Salmani ${ }^{4}$ \\ ${ }^{1}$ Najran University Kingdom of Saudia Arabia \\ ${ }^{2}$ Atlantic International University, United States of America \\ ${ }^{3}$ MGIMO University, Russia \\ ${ }^{4}$ School of Health Management and Information Sciences, Iran University of Medical Sciences, Tehran, Iran.
}

\section{Article Info \\ Article history: \\ Received May 25, 2018 \\ Revised Jun 20, 2018 \\ Accepted Jul 26, 2018}

\section{Keyword:}

Educational Applications

Mobile learning

Teaching Strategies.

\begin{abstract}
This article aims to outline different pedagogical strategies with applications (apps) in the classroom. Every year the use of mobile devices like tablets and smartphones increases. At the same time, applications are being developed to meet this demand. It is therefore essential that educators investigate their use as a motivational technological medium that can possibly be used in the classroom. Apps can be used both as a source of information as well as a tool for creating material. Thus, this article will present the results of a study applying teaching strategies in different contexts. It therefore highlights the importance of mobile learning as a viable alternative in the classroom. In order to do so, there was a multiple case study in the undergraduate pedagogy program and a digital inclusion course for seniors, both offered in the first semester of 2017 at the Federal University of Rio Grande do Sul (UFRGS). Educational applications and examples of teaching strategies using apps were created in these classes. Educational applications offer the possibility to bring innovations to teaching practices, as well as new forms of communication, interaction and authorship, thus contributing to the process of teaching and learning.
\end{abstract}

Copyright $(2) 2018$ Institute of Advanced Engineering and Science. All rights reserved.

\section{Corresponding Author:}

Shazia Zaheer, Faculty of Science and Arts Sharurah, Najran University Kingdom of Saudia Arabia Email: Shaziazaheer_17@yahoo.com

\section{INTRODUCTION}

The number of mobile devices being produced and offered to Australian increases every year. In "The Australian Media Study" [1] the cellular phone was ranked as the second means of accessing the Internet (66\%), followed by the tablet (7\%). This shows that Australian use phones for different purposes, including to access digital Internet tools. There are different reasons for this, including the quick learning curve to use these devices (mainly due to the interactive touch screen), mobility, usability [2-4], fast communication and frequent updates. With this context in mind, it is important that the development of this new mode of communication and reasoning is also incorporated in the classroom to keep up with the changes in society. Thus, one can prepare a subject to use mobile technology not only for entertainment, but also for educational goals and to meet their daily life needs more productively [5].

One of the most commonly used tools on mobile devices are applications, or digital resources designed to carry out certain tasks such as communicating, playing, creating text, etc. Currently there are about 1.43 million applications (apps) available on Google Play (https://play.google.com/store?hl=pt-BR), and 1.21This paper is structured in six sections. The first addresses the concept of mobile learning (section 2). Then section 3 describes the methodology used in this study. Next examples of the use and construction of educational applications supported by educational strategies are presented in section 4 . Lastly, section 5 presents the conclusions. 


\section{MOBILE LEARNING}

Currently, mobile technology is the increasingly used in different sectors of society. Education, in turn, needs to be constantly updated in order to support its students. This brings new challenges in the educational sector, such as the Mobile Learning approach (M-Learning).

M-Learning, incorporates the use of mobile technologies, separately or together with other Information and Communication Technologies (ICT) [6-8]. Thus, this type of technology can provide students with possibilities to construct and improve knowledge at any time or place. According to Leite [9], M-Learning can occur in situations where technologies can offer the student means to build their knowledge. However, a simple random use of a mobile device to perform an isolated activity in the classroom is not mobile learning. In order to be effectively understood as such, the teacher needs to integrate the use of technology with pedagogical planning that involves the study of content, teaching materials, implementation strategies and activities.

In addition to supporting academic activities, this type of learning can also aid the interaction and communication among those involved in the educational process. According to Batista [10], M-Learning provides opportunities to unite people in real and virtual worlds, creating learning communities among teachers and students. This occurs with the aim to integrate the process of teaching and learning with the use of mobile technologies. Therefore, there is the need to create one or more teaching strategies to support this educational process, or a possible set of educational activities that can be applied according to the individual and/or collective needs of students [11-13]. One possibility is the use of applications in the classroom, which will be discussed below.

\subsection{The use of educational applications in the mobile learning process}

Applications (apps), as described above, are programs designed especially for mobile platforms such as smartphones and tablets [14]. When used in the classroom, they can become an educational resource [15], capable of providing an innovative, dynamic, interactive, collaborative and even playful knowledge building process. There are tools that allow teachers and students to build their own educational applications. Some of these are available in free versions. For example, the Fábrica de Aplicativos (http://fabricadeaplicativos.com.br/) enables the creation of applications for mobile devices in different areas, offering a reasonable amount of features.

This perspective contends that the construction and use of apps can be integrated into educational objectives, challenging educators and students and also prompting innovations in teaching and learning. In addition, app-building is a way to mediate learning with the use of mobile devices in the classroom. Therefore, instead of prohibiting the use of these devices, pedagogical strategies must be created to bring the educational environment closer to the current social reality.

Hence, it is argued that teachers and students may gradually find new ways to use applications. They will no longer be solely for entertainment, but increasingly used to solve everyday problems. Autonomy, collaboration and interaction are also motivated by this strategy, since students can take an authorial stance from the search for useful applications to their creation and sharing of this resource with the class. It is also a way to unite theory and practice, enabling the construction of meaning for the covered content.

However, simply using applications is not sufficient to support educational goals. It is necessary to formulate pedagogical strategies that integrate the elements involved in the process of teaching and learning to promote quality education. Thus, the following sections will present some pedagogical strategies used for this study to address the creation and use of applications in the classroom.

\section{METHODOLOGY}

This paper explores pedagogical strategies that can be adopted to create educational applications. The research is descriptive theoretical-practical, because it is dedicated to the (re)construction of ideas and improvement of principals related to studies of mobile learning and authorship. In order to meet the proposed objectives, the study was conducted in three recursive steps. 1) Construction of the theoretical framework of the themes: mobile learning, mobile devices, educational applications, authorship. 2) Planning and implementation of the class and workshop: the intention was to plan and implement teaching strategies that include the author's development of educational applications. An undergraduate course and a continuing education workshop were used. 3) Development of educational strategies for the educational use of applications: This step was based on the theoretical framework and the results obtained in the undergraduate course and continued education workshop. 
There were two data collection instruments used: a) Participant observation; b) Data collected through the productions in AVA features. The following section presents the trajectory and results of this research.

\section{TRAJECTORY AND RESULTS}

The construction of educational apps in the classroom involved students in research (they had to research about the applications and themes for them). Moreover, they had to read, understand texts and write for their applications. Hence, this multiple case study involved two groups of students, an undergraduate pedagogy course and an extension course for seniors. This enabled analysis of how educational applications can enhance the teaching and learning of students through M-Learning.

\subsection{The construction of applications in a pedagogical undergraduate course}

Building an application in the undergraduate course began by planning a group task, which was to design and develop an educational app. The themes were to be related to topics studied in class or about information technology in education, an issue closely linked to the subject of the class. It asked for the apps to present a theme (in the application description), suggestion of an educational app, application tips, examples from videos, photo album, audio, references and credits (authors) [16].

The activity began in the week that discussed the topic "Mobile Learning," lasting for 14 more days (including distance learning). At the end of this time, students posted the application link in the virtual learning environment ROODA. This is a virtual environment platform for distance learning (https://ead.ufrgs.br/rooda/), which was used to plan and organize the "Media, Digital Technologies and Education" class offered in the first half of the daytime pedagogy course offered in the first semester of 2017 at UFRGS /Brazil. This application has provided support for this research.

Examples of apps produced in this undergraduate course are presented below (Figures 1 and 2). These applications can be accessed at the online address provided and installed on a mobile device. They are still available on the Internet and not through any specific mobile device app store.

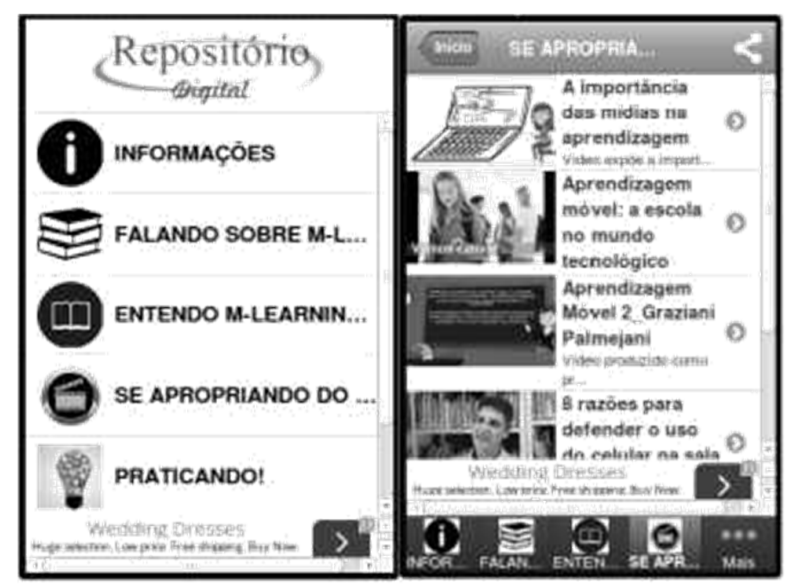

Figure 1. Example of an application made by a student in the education class. Available at: http://galeria.fabricadeaplicativos.com.br/repositorio_digital 


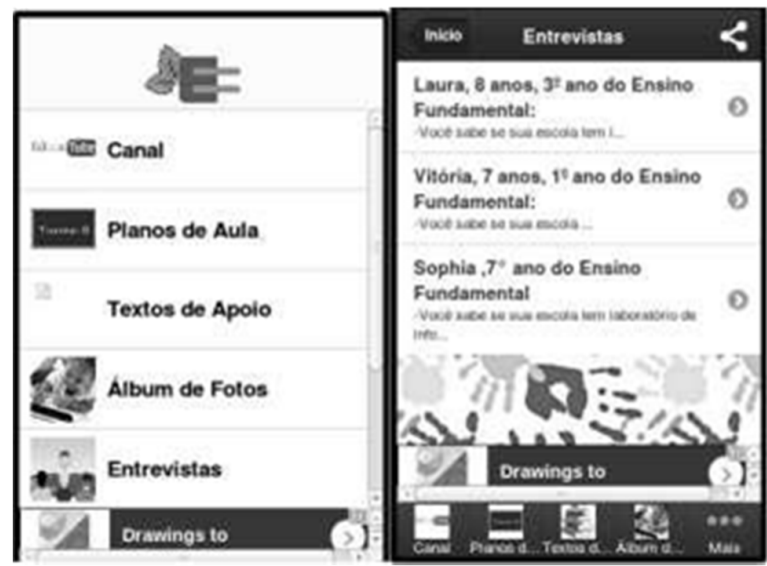

Figure 2. Example application made by a student in the education class. Available at: http://galeria.fabricadeaplicativos.com.br/infoplan-turmab-midias\#gsc.tab=0

\subsection{Construction of applications in an elderly digital inclusion course}

Research about the use of applications by the elderly is still quite recent and there are few apps geared toward this population. Those available are primarily related to the health of the elderly (medication warnings, diabetes control, etc.). It is worth inquiring when education will produce applications and/or investigate teaching strategies that meet the elderly's other needs (social, cultural, technological, etc.). Therefore, there is a demand exists to create pedagogical strategies that can assist in the elderly's critical development through, for example, authorship.

The Digital Inclusion Unit (UNIDI) of the Federal University of Rio Grande do Sul (UFRGS) offered a distance learning/classroom workshop for seniors in [5], called "Between cultures in southern Brazil: The elderly's view of the city Porto Alegre." The workshop lasted for five months, with two hour weekly meetings. The goal was for the elderly to create applications to present the city where they live and the most interesting places to go and tourist sites for for other seniors to visit.

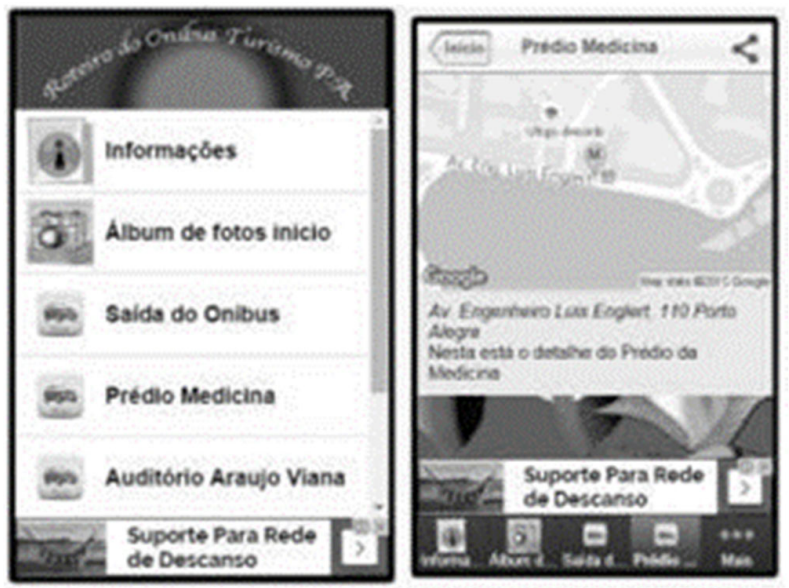

Figure 3. Example of an application developed by a student in the class for the elderly. Available at: http://galeria.fabricadeaplicativos.com.br/onibusturismopa

\subsection{Outline of pedagogical strategies}

The results of these strategies are seen point to the valid contribution of the creation of an educational application to building and sharing of information, knowledge and concepts collaboratively. Thus, it was taken into consideration the fact that the activity has been published on the ROODA Webfolio in a format visible to all, enabling one to go to the address (URL) of the app developed in the class and 
extension course for seniors. Moreover it allowed all students to view their peers' work on their mobile devices. They could download the applications that they were interested in, about the theme and/or interactive content, providing a less linear reading, containing video, audio, images, links and others.

It is possible to outline some pedagogical strategies that can assist in the production of applications in the classroom based on this research and experience:

- Planning: In addition to outlining the objectives of the educational proposal, it is important to decide the subject of applications with the students so that they are involved and motivated to develop the apps;

- Materials: It is important to plan a time to collect materials for the application. A class on how to collect materials (photo, images on the Internet; videos, etc.) is also necessary, as well as one on how to separate information into specific folders on the computer to find it easier when it is time to create the app;

- Features to create Apps: It is difficult to find features for building applications that are easy to use and are also in Portuguese. There are few tools for laymen. The strategy used in the two examples presented in this article is found in the Fábrica de Aplicativos (http://fabricadeaplicativos.com.br/). Although it is relatively easy to use on the computer, this feature limits the tools that can be included in the app.

- Copyright: It is very important to take precautions regarding copyrights on materials produced and applications. One must be extra careful, because these apps can be accessed and downloaded on mobile devices by anyone in the world.

- Educational goal: Without an educational goal, applications provide little student involvement and can even be discouraging. The clarity of educational objectives in building the app, for the teacher as well as

These were some possible pedagogical strategies that can be adopted by teachers at different levels and types of education. There is still a great deal of research to be done and much to be proposed in this field [17]. However, it has been shown that the development of educational applications in the classroom is extremely compelling and challenging for students. It motivates them to continue learning and developing other applications of interest and can help them to acquire knowledge[18][19].

\section{FINAL CONSIDERATIONS}

This work has shown that the use and construction of educational applications as a pedagogical and authorial strategy is relevant. In fact, it has the potential to generate innovation in schools, offer new and different possibilities in the teaching and learning process, and help students to better understand content and information.

Thus, mobile learning presents innovations and challenges for its implementation such as connectivity, portability, flexibility, autonomy of students and new forms of communication and interaction. In conclusion, mobile learning is now being developed. It is therefore still necessary to research and understand this tool and its possibilities in education. Hence, this article hopes to provoke reflection on mobile learning in schools, aiming to collaborate by strengthening the related concepts and aid in the use and development of educational applications in the classroom.

\section{REFERENCES}

[1] Brasil. Presidência da República. Secretaria de Comunicação Social. Pesquisa brasileira de mídia 2015: hábitos de consumo de mídia pela população brasileira. - Brasília: Secom, 2014. 153 p. : il. ISBN: 978-85-85142-60-5

[2] Butt, S. M., Majid, M. A., Marjudi, S., Butt, S. M., Onn, A., \& Butt, M. M., "Casi Method for Improving The Usability of Ids". Science International, 27(1), 2015.

[3] Butt, S. M., Ahmad, W. F. W., \& Fatimah, W., "An overview of software models with regard to the users involvement”. International Journal of Computer Science Issues (IJCSI), 9(3), 1, 2012.

[4] Butt, S. M., \& Ahmad, W. F. W., "Overview of Systems Design and Development with Regards to the Involvement of User, HCI and Software Engineers". International Journal of Computer Applications, 58(7), Pp.14, 2012.

[5] Butt, S. M., Onn, A., Butt, M. M., Inam, N. T., \& Butt, S. M., "Incorporation of usability evaluation methods in agile software model". In Multi-Topic Conference (INMIC), IEEE 17th International, Pp. 193-199, 2014.

[6] UNESCO., "Policy Guidelines for Mobile Learning". Publicado pela Organização das Nações Unidas para a Educação, a Ciência e a Cultura (UNESCO), 7, place de Fontenoy, 75352 Paris 07 SP, France. A tradução para o português desta publicação foi produzida pela Representação da UNESCO no Brasil, 2013.

[7] Ahmad, W. F. W., Butt, S. M., \& Rahim, L., "Usability evaluation of the agile software process", In International Visual Informatics Conference, Springer, Cham. pp. 640-651, 2013.

[8] Butt, S. M., Ahmad, W. F. W., \& Rahim, L., "Handling tradeoffs between agile and usability methods". In Computer and Information Sciences (ICCOINS), International Conference on, IEEE, Pp. 1-6, 2014, 2014.

IJERE Vol. 7, No. 3, September 2018: $188-193$ 
[9] Leite BS. "M-Learning: o uso de dispositivos móveis como ferramenta didáti-ca no Ensino de Química”. Revista Brasileira de Informática na Educação, 22(3), 2014.

[10] Batista SCF, Behar PA, Passerino LM, editors., M-learnMat:”Aplicação de um Modelo Pedagógico para Atividades de M-learning em Matemática," Brazilian Symposium on Computers in Education (Simpósio Brasileiro de Informática na Educação-SBIE), 2011.

[11] Behar PA., "Modelos pedagógicos em educação a distância: Artmed Editora," 2009.

[12] Domingo, M. G., \& Garganté, A. B., "Exploring the use of educational technology in primary education: Teachers' perception of mobile technology learning impacts and applications' use in the classroom". Computers in Human Behavior, 56, Pp. 21-28, 2016.

[13] Santos F, Freitas S. “Avaliação da usablidade de ícones de aplicativo móvel utilizado como apoio educacional para crianças na idade pré-escolar". Ação Ergonômica. Revista Brasileira de Ergonômia, 10(2), 2015.

[14] TECMUNDO., Play Store passa App Store em número total de aplicativos e desenvolvedores, 2015.

[15] Bento MCM, Cavalcante RdS., "Tecnologias Móveis em Educação: o uso do celular na sala de aula". Educação, Cultura e Comunicação, 4(7), 2013

[16] Butt, S. M., Navarro, K. F., Shorab, M., Butt, S. M., \& Onn, A., "Using Mobile Technology to Improve Nutritional Information of Diabetic Patient's", In New Advances in Information Systems and Technologies, Springer, Pp. 3-11, 2016.

[17] Reychav, I., Dunaway, M., \& Kobayashi, M., "Understanding mobile technology-fit behaviors outside the classroom”. Computers \& Education, Pp. 87, 142-150, 2015.

[18] Lindsay, L., "Transformation of teacher practice using mobile technology with one to one classes: M learning pedagogical approaches". British Journal of Educational Technology, 47(5), Pp.883-892, 2016.

[19] Heflin, H., Shewmaker, J., \& Nguyen, J., "Impact of mobile technology on student attitudes, engagement, and learning”. Computers \& Education, Pp.107, 91-99, 2017. 